\title{
Prevalence and Pattern of Workplace Violence and Ethnic Discrimination among Workers in a Tertiary Institution in Southern Nigeria
}

\author{
K. E. Douglas ${ }^{1 *}$, A. K. Nkporbu ${ }^{2}$ \\ ${ }^{1}$ Department of Preventive and Social Medicine, University of Port Harcourt Teaching Hospital, Port Harcourt, Nigeria \\ ${ }^{2}$ Department of Neuropsychiatry, University of Port Harcourt Teaching Hospital, Port Harcourt, Nigeria \\ Email: ^drohambele1@yahoo.com
}

How to cite this paper: Douglas, K.E. and Nkporbu, A.K. (2017) Prevalence and Pattern of Workplace Violence and Ethnic Discrimination among Workers in a Tertiary Institution in Southern Nigeria. Open Access Library Journal, 4: e3464.

https://doi.org/10.4236/oalib.1103464

Received: February 17, 2017

Accepted: March 18, 2017

Published: March 21, 2017

Copyright $\odot 2017$ by authors and Open Access Library Inc.

This work is licensed under the Creative Commons Attribution International License (CC BY 4.0). http://creativecommons.org/licenses/by/4.0/

\section{Open Access}

\begin{abstract}
Background: Work and work environment are important influences on both health and production. Psychosocial hazards, including Work place occupational violence and racial discrimination, may be assuming a major place in occupational health and safety, especially in developing countries like Nigeria. Work place occupational violence and racial discrimination, though appears latent, equally appears to receive little attention in workplaces. Aim: The study was to assess the prevalence and pattern of workplace violence and racial discrimination as work place psychosocial hazards in a tertiary University in Southern Nigeria. Methodology: Following approval from the Research Ethic Committee of the University of Port Harcourt, 600 consenting staffers of the University of Port Harcourt were recruited by systematic random sampling and pretested structured closed ended self administered questionnaire and adapted Matrix Risk checklist were used for data collection from respondents. Results were presented via descriptive and analytical methods. Results: Work place violence, i.e, physical assault had a prevalence of $9.9 \%(\mathrm{n}=55)$. Also Ethnic/tribal discrimination had a $7 \%(\mathrm{n}=39)$. Risk factors included work load $(98.2 \%)$ home-work interface $(82.0 \%)$, career $70.1 \%$, interpersonal relationship (64.0\%), work schedule 53\%, lack of career development $58.7 \%$, unfair target or goals $46.2 \%$, job security $20.1 \%$ and working alone or night work $21.7 \%$. Conclusion: Work place occupational violence and racial discrimination with its attendant preventable risk factors is present among workers at the University of Port Harcourt. There is need by the University to adopt and enforce appropriate occupational health and safety policies and measures to prevent and control this psychosocial hazard.
\end{abstract}

\section{Subject Areas}

Psychiatry \& Psychology, Public Health 


\section{Keywords}

Workplace Violence, Ethnic Discrimination, Workers, Tertiary Institution

\section{Introduction}

Psychosocial hazards constitute a unique challenge to Occupational Health and Safety profession [1] [2] [3] [4]. Reports by the World Health Organization indicate that approximately $30 \%-50 \%$ of workers report deleterious exposure to physical, chemical or biological hazards. Again, an equal percentage of workers report psychological stress and overload (including workplace violence, physically assault, verbal abuse, unfairness and inequality, threat and ethnic discrimination) at work with associated health effect [5] [6] [7] [8] [9]. Sadly, these unhealthy situations are on the increase in our modern day work environment.

The term "workplace violence" applies to all forms of physical assault at work (i.e. striking, kicking, scratching, biting, spitting or any type of direct physical contact, pushing, shoving, tripping, grabbing, throwing objects, attacking with any type of weapon and any form of assault to anybody in a subordinate position) [1]. A "physical attack" can take place irrespective of the attacker's intent and includes situations where an employee is attacked by a person who may not be able to form intent, but their behaviour can cause harm [1].

There is also third party violence from clients, customers, patients or pupils [10]. The Fourth European Working Conditions Survey (2007) showed that 6\% of the workforce was exposed to threats of physical violence, violence by other people $4 \%$ and psychological harassment $5 \%$ at work over the past 12 months [11].

In the context of societal inequality, additional workplace hazards may include, various forms of violence, racial or ethnic discrimination, sexual harassment, and workplace abuse-with the first two also encompassing experiences that occur both in and outside work. [9] [12]-[18]. About 58 percent of the workers of color ( $65 \%$ of the black participants, $45 \%$ of the Latino participants, and $63 \%$ of the participants of additional race/ethnicities), compared with 37 percent of the white participants, reported having experienced racial discrimination in a study [19]. The first three groups together, moreover, were 3.5 times more likely than the white participants to have encountered racial discrimination in three or more specified situations ( $36.7 \%$ vs. $10.2 \%)$, with black workers at greatest risk (4.3-fold) [19].

A number of risk factors have been associated with occurrence of work place psychosocial hazards including work place violence and ethnic discrimination [20] [21] [22] [23] [24]. As concerns work content, the priorities identified pertain to time pressure and high job demands, discrepancies between abilities, skills, job demands and expectations, poor management practices and lack of participation in decision-making. There is high consensus on job insecurity, which has been identified as a global psychosocial risk. Precarious employment 
(that is related to job insecurity) has resulted in relatively high consensus as well. Furthermore, high consensus has been reached on a perceived imbalance on abilities, resources and support as a psychosocial risk. Interpersonal relationships present psychosocial risks, and with less pronounced consensus also poor physical conditions. Lastly, lack of control or participation in decision has also been blamed in a study [19].

Work place violence and ethnic discrimination are more prevalent in the service sector, and indeed the risk of experiencing both threats of violence and psychological harassment is greatest in the education and healthcare sectors, in public administration and defense [25]. In the transport, communication, hotel and restaurant sectors and in education, the risk is found to be higher than the average [25].

The education sector is one of the most important vibrant, dynamic and core sectors of any thriving economy. The education sector drives and cuts across virtually all other sectors. It is the breeding place for human resources for all other sectors. As such it is tasked with enormous responsibilities, and so also are the workers. It caters for massive population of youths amidst depressed economy, increasing delinquency and social vices. This becomes more glaring when viewed against the backdrop of globalization and modernization [26]. However, it should be born in mind that in a growing economy, the effect of globalization is not significantly felt [26]. In developing nations, like Nigeria, economy and infrastructures are mostly still rudimentary and workers often compensate for these deficiencies and inadequacies by working most times with crude instruments, prolonged duration, and increased workload per worker with often resultant adverse health outcomes [27] [35]. In the Delphi study, African participants felt that the education and teaching sector was one of the sectors most associated with psychosocial hazards as high as $56 \%$ [19].

Many studies have associated chronic stress in the workplace with a range of negative physical, psychological and social consequences for employees. These include depression, anxiety, burnout, increased alcohol use, smoking, aggression, anger, violence, road rage, poor family interactions, declining marital cohesion [3] [6] [20] [28]-[34], as well as cardiovascular disease, musculoskeletal disorders (MSDs) [28] [36] and hippocampal impairment [8]. Workplace hazards have also been associated with high staff turnover and absenteeism, increased industrial accidents and insurance premiums claims, decreased job performance, loss of productivity and reduce morale among employee [3] [7] [24] [33] [37]. In spite of all these, so little is still being done. Some experts reiterate that the lack or insufficiency of funding allocations retards the development of international occupational health introduction of safety programmes and policies. This has equally been blamed partly on the fact that other health issues compete with occupational health.

\section{Aim}

The aim of this study therefore was to assess the prevalence and pattern of work 
place violence and ethnic discriminations among Workers at the University of Port Harcourt.

\section{Methodology}

\subsection{Study Design}

This is a descriptive cross-sectional study.

\subsection{Study Area and Population}

Established 1975, the federal University of Port Harcourt (UNIPORT) is situated along East-West road, Choba, in Rivers State. As an academic environment, it has both students, academic as well as non academic staff.

The University currently has staff strength of about four thousand six hundred and fifty five (4655) workers catering for a student's capacity of between 60,000 to 70,000 spread across four Colleges, nine Faculties and four Schools. The University of Port Harcourt, being a federal public educational institution, its work force has been made to as much as possible reflect the federal character principle of Nigeria. The staff categories are along academic and non-academic staff. The academic staff included graduate assistants, assistant lecturers, lecturers 1 and 2, senior lecturers, readers and professors, academic contract staff and those on sabbatical leave. The non-academic Departments/Units include those of Central Administration, Bursary, Library, Works, Security, Transport, Cleaners and Dispatchers. All academic staff are Senior staff while the non-academic staff are made up of both Junior and Senior staff. Majority of the study population were enlightened individuals with at least basic educational qualifications.

Only bonafide staff of the University of Port Harcourt, Staff who have given their informed consent, Adults aged between 18 years and 70 years and those who had worked not less than 2 years in the institution were included while casual staff and staff less than two years in employment were excluded.

\subsection{Sample Size and Sampling Methods}

The sample size was calculated using the formula for comparism of proportions by Araoye [38]. A stratified method of sampling was used first and later followed by a systematic random sampling to identify each subject from the various Departments of University of Port Harcourt.

\subsection{Study Instruments}

A well-structured open ended socio-demographic and study questionnaire was used. The structured questionnaire, which was self-administered, was written in simple English and contained sections on socio-demography (age, sex, address, occupation, tribe and religion), psychosocial hazards related to institution of higher learning), and suggested solutions. The Risk Matrix Assessment instrument [54] was used. A Walk through Survey which is an on the spot, impromptu, unannounced, uninformed, immediate assessment of any work place was also used. A pilot study was conducted using sampled population in the Rivers State 
University of Science and Technology, Port Harcourt, who satisfied the inclusion criteria, and these were not included in the main study.

\subsection{Data Management, Presentation and Analysis}

Analysis of results involved the use of the twentieth edition of the statistical package for social sciences (SPSS-20, 2014) software. Descriptive statistics was calculated for all variables. For continuous variables, means and standard deviations (SD) and analysis of variance were computed. For categorical variables, descriptive statistics included the numbers and proportions in each category. Frequency distributions and cross tabulations were generated and chi-square test of significance was calculated. The conventional $5 \%$ of level of significance was set. Confidence interval was set at $95 \%$ and $\mathrm{P}$-value of less than 0.05 was considered statistically significant.

\subsection{Ethical Considerations}

Approval for the study was obtained from the Ethical Committee of the University of Port Harcourt. Informed consent was equally obtained from all participants. Health education and awareness was carried out for the participants after completing the questionnaires. Meetings were held with staff, management and both staff and management in that other, after the Walk Through Survey to intimate them of the outcome.

\subsection{Limitation of the Study}

During the work through survey, assessing all the facilities in the University to ascertain the safety of work environment was a little bit difficult. Secondly, some of the staff who had experienced some form of workplace psychosocial hazards, particularly sexual harassments, may have declined from admitting on the questionnaire due to cultural reasons.

\section{Results}

\subsection{Socio Demographic Characteristics of Study Participants}

The predominant age groups were those between 36 - 45 years old with $(\mathrm{n}=199$, $33.2 \%)$, males $(n=299,50 \%)$, married group $(n=452,75.6 \%)$, those with tertiary education $(n=501,83.8 \%)$ and urban dwellers $(n=245,41.0 \%)$. High levels of experience of psychosocial hazards included age group 36 - 45 (68.3\%), female $(80.7 \%)$, divorce $(80.0 \%)$, secondary education $(75.6 \%)$, Christianity (60.8\%), Ikwerre (65.8\%), and semi-urban dwellers (59.2\%). See Table 1.

\subsection{Prevalence of Work Place Violence and Ethnic Discrimination among Workers at University of Port Harcourt}

Verbal aggression was the most common work place violence in the study with 136 (24.4\%), followed by physical assault with 55 (9.9\%). In all forms of work place violence studied, junior staff were more affected compared to senior staff except in physical assault where senior staff were more affected. However, this 
Table 1. Socio Demographic Characteristics of Respondents.



appeared to be mere effect of over representation. Ethnic discrimination had 37 (7.0\%) and the junior staff were most victims. See Table 2. 
Table 2. Showing the Prevalence of Work Place Violence and Ethnic Discrimination among Workers at University of Port Harcourt.

\begin{tabular}{|c|c|c|c|c|c|}
\hline \multirow[t]{2}{*}{$S / N$} & \multirow{2}{*}{$\begin{array}{l}\text { Psychosocial } \\
\text { hazards }\end{array}$} & \multirow{2}{*}{$\begin{array}{c}\% \text { of people who } \\
\text { have } \\
\text { experienced } \\
\text { psychosocial } \\
\text { hazards }\end{array}$} & \multirow{2}{*}{$\begin{array}{l}\text { \% who have } \\
\text { not } \\
\text { experienced } \\
\text { psychosocial } \\
\text { hazards }\end{array}$} & \multicolumn{2}{|c|}{$\begin{array}{l}\text { Of the No. who have } \\
\text { experienced } \\
\text { workplace violence } \\
\text { and ethnic } \\
\text { discrimination. }\end{array}$} \\
\hline & & & & $\begin{array}{c}\text { Junior } \\
\text { Staff } \\
\mathrm{n}=42\end{array}$ & $\begin{array}{c}\text { Senior } \\
\text { Staff } \\
\mathrm{n}=516\end{array}$ \\
\hline \multirow{6}{*}{1.} & Work place & & & & \\
\hline & Violence & & & & \\
\hline & a. Verbal aggression. & $136(24.4)$ & $422(75.6)$ & $33(78.6)$ & $103(20.0)$ \\
\hline & b. Threats & $35(4.4)$ & $523(93.7)$ & $31(73.8)$ & $4(0.8)$ \\
\hline & c. Physical aggression & $51(9.2)$ & $507(90.9)$ & $26(61.9)$ & $25(4.8)$ \\
\hline & a. Physical assault & $55(9.9)$ & $503(90.1)$ & $16(38.1)$ & $39(67.6)$ \\
\hline 2. & $\begin{array}{c}\text { Ethnic } \\
\text { Discrimination } \\
\text { a. Ethnic } \\
\text { discrimination }\end{array}$ & $39(7)$ & $519(93.0)$ & $29(69.0)$ & $10(1.9)$ \\
\hline
\end{tabular}

\subsection{Frequency of Occurrence of Psychosocial Hazards among Workers of University of Port Harcourt}

The few cases of work place violence and ethnic discrimination were occasional in occurrence and fewer were regular. Very regular recorded none while majority of respondents said the psychosocial hazards were rare. See Table 3.

\subsection{Pattern of Perpetrations of Psychosocial Hazards among Workers at the University of Port Harcourt}

Boss constituted higher perpetrators compared to subordinate in all cases of work place violence and ethnic discrimination. See Table 4.

\subsection{Suggested Possible Solutions that Could Reduce Work Place Violence and Ethnic Discrimination at the University of Port Harcourt}

Periodic in-service training was the most identified possible solution with 428 (76.70\%) followed by enlightenment of University workers with 386 (69.18\%). See Table 5.

\section{Discussion}

From the study, the age group that had the highest prevalence of psychosocial hazards was age of $36-45$ years, followed by that of $26-35$ years. This are also the age groups that were most represented in the study. This is expected because this age ranges form the most active age of labour with possibly the highest experience and as such, they may be under active pressure to perform and deliver. It suffices to mention that most employers make this age range a criterion for employment [26]. There was a statistically significant relationship between age and experience of psychosocial hazards $(\mathrm{p}=0.041)$. 
Table 3. Showing the frequency of occurrence of psychosocial hazards among workers of University of Port Harcourt.

\begin{tabular}{|c|c|c|c|c|c|c|}
\hline $\mathrm{S} / \mathrm{N}$ & $\begin{array}{l}\text { Psychosocial } \\
\text { hazards }\end{array}$ & & $\begin{array}{c}\text { Very } \\
\text { Regular } \\
(\%)\end{array}$ & $\begin{array}{c}\text { Regular } \\
\text { (\%) }\end{array}$ & $\begin{array}{c}\text { Occasional } \\
(\%)\end{array}$ & $\begin{array}{c}\text { Rare (\%) } \\
\text { (does not } \\
\text { occur) }\end{array}$ \\
\hline \multirow{5}{*}{1} & Occupational & & & & & \\
\hline & Violence & & & & & \\
\hline & b. Physical attack & 558 & $0(0.0)$ & $7(1.3)$ & $48(8.6)$ & $503(90.1)$ \\
\hline & a. Verbal aggression & 558 & $0(0.0)$. & $30(5.4)$ & $106(19.0)$ & $422(75.7)$ \\
\hline & a. Physical aggression & 558 & $0(0.0)$ & $7(1.3)$ & $44(7.9)$ & $507(90.9)$ \\
\hline \multirow{4}{*}{2.} & b. Threats & 558 & $0(0.0)$ & $6(17.1)$ & $11(31.4)$ & $18(51.4)$ \\
\hline & Racial & & & & & \\
\hline & Discrimination & & & & & \\
\hline & $\begin{array}{c}\text { b. Racial } \\
\text { discrimination }\end{array}$ & 558 & $0(0.0)$ & $7(1.3)$ & $32(5.7)$ & $519(93.0)$ \\
\hline
\end{tabular}

Table 4. Pattern of perpetrations of psychosocial hazards among workers at the University of Port Harcourt.

\begin{tabular}{ccc}
\hline Social Hazards & \multicolumn{2}{c}{ Perpetrators } \\
\hline 1. & Occupational violence & Subordinate \\
a. Verbal Aggression & $109(80.1 \%)$ & $27(19.9 \%)$ \\
b. Physical aggression & $38(74.5 \%)$ & $13(25.5 \%)$ \\
c. Physical Assault & $46(83.6 \%)$ & $9(16.4 \%)$ \\
d. Threats & $23(65.7 \%)$ & $12(34.2 \%)$ \\
Racial Discrimination & & $13(33.3 \%)$ \\
\hline
\end{tabular}

Table 5. Showing percentage suggested possible solutions that could reduce work place violence and ethnic discrimination at the University of Port Harcourt.

\begin{tabular}{ccc}
\hline S/N & ITEMS & Percentage responses (\%) \\
\hline 1 & Enlightenment of University workers (EUW) & $386(69.18 \%)$ \\
2 & Periodic in-service training (PIT) & $428(76.70 \%)$ \\
3 & $\begin{array}{c}\text { Introduction of occupational health and safety } \\
\text { programmes in the University (IOHSP) }\end{array}$ & $293(52.40 \%)$ \\
4 & Others (O) & $9(1.62 \%)$ \\
\hline
\end{tabular}

From the study, males were predominant. This is supported by previous study [4] [39]. This may equally simply reflect the recruitment pattern of the University. However, more females tended to have experienced psychosocial hazards reflecting reports in available literature [21] [40]. This relationship however was not statistically significant $(\mathrm{p}=0.972)$. Despite the fact that majority of the respondents were married, the single appeared to have recorded the highest prevalence of experiences of psychosocial hazards. This may reflect the fact that singlehood may offer some subtle higher exposure vulnerability to the different forms of workplace violence and ethnic discrimination [41]. However, the relationship between marital status and experience of psychosocial hazards in this 
study was not statistically significant $(\mathrm{p}=0.740)$.

The study found that those with lower level of education (lower academic qualification refers to primary and secondary education) experience higher prevalence of psychosocial hazards compared to those who possess higher academic qualification. This may be a reflection of the fact that those with higher level of education will naturally be placed at higher position and as such would play the role of bosses and have tendency to give order, command and possibly exert lordship and rulership over those with lower academic qualification. This may sometime be unfriendly over their subordinates. The relationship between level of education and experience of psychosocial hazards was found to be statistically significant $(\mathrm{p}=0.001$ ). This finding is consistent with previous studies which have noted that experience of psychosocial hazards is more prevalent in lower socioeconomic occupations and disadvantaged occupational classes [16] [41] [42]. Furthermore, the lower the socioeconomic position, the higher the risk of exposure to adverse and stressful working conditions [15] [43], and also more vulnerable to poorer health [42].

Majority of the respondents were indigenes of Rivers State. This may simply be a reflection of the fact that the University is situated in Rivers State. However, there was a statistical relationship between ethnicity and experience of psychosocial hazards in this study $(\mathrm{p}=0.038)$. This finding agrees earlier documentation that for minority groups, ethnic discrimination is a stronger predictor of health outcomes than are traditional job stresses [33].

Duration in employment and category staff both did not show any statistically significant relationship with experience of psychosocial hazards. However, the study found that psychosocial hazards were more experienced by workers with shorter duration of stay in employment than the longer staying staff. A possible explanation to this observation is that the younger staff may still be new to their job, with little experience, more prone to making mistakes that may warrant yelling, and may not have known their rights adequately [30], at such may be vulnerable to undue intimidation and harassment.

Of all the forms of occupational violence studied, verbal aggression was the highest followed by while threats was the least. Studies have identified most perpetrators of verbal aggression as people who have poor anger control and/or management [18]. However, verbal aggression has being identified to follow sometimes repeated corrections or warnings to a staff. In few instances, subordinates have being found to be verbally aggressive to their bosses.

The prevalence of physical attack in this study was $9.9 \%(n=55)$. The lower prevalence of threat and physical attack in this study may be due to the fact that workers are aware of the punishment that such behavior may attract if a staff is found to be culpable. Most cases of physical attack and threat at work place are associated with substance abuse particularly alcohol. is generally high outside the work place [13]. However, the low occurrence of physical attack or threat observed in this study may be due to the fact that workers may not be permitted to use any of the psychoactive substances in their workplaces particularly during 
working hours. Alcohol is a sedating psychoactive substance and as such could render the worker drowsy on his or her work, making it obvious [44]. For this reason, many workers who use alcohol may choose to take it after work.

Physical aggression may equally have being low in this study because workers may be aware that it carries very fierce punishment including dismissal. For both physical attack and verbal aggression, and indeed all other forms of workplace abuse, calls have been made for a thorough employment selection measures including detailed personality assessment and possibly mental health evaluation as part of the pre-employment and pre-placement medical examinations [45] [46].

Verbal or physical aggression and physical assault all form a continuum and can occur in fast progression by a perpetrator, who may have the same line of personality traits [1] [5] [47]. A "physical attack" can take place regardless of the attacker's intent and includes situations where an employee is attacked by a person who may not be able to form intent, but their behaviour is capable of causing harm [34]. In the community services sector, the main threat of violence is from clients or residents. However, violence in the workplace can be perpetrated by co-workers (including managers, supervisors or employers), people known to the organization (such as family members of people in care) and intruders [1] [5] [48].

The finding from this study relating to occupational violence is similar to other report which also stresses that $6 \%$ of the European workforce had been exposed to threats of physical violence, $4 \%$ to violence by other people and $5 \%$ to psychological harassment at work over the past 12 months [17]. Violence and psychological harassment at work are considered psychosocial risk factors. In fact, poor interpersonal relationships have been demonstrated to be a significant antecedent of the stress process when they are characterized by behaviour that is harassing or abusive [17] [49].

From the study, however, majority of the respondents said occurrence of occupational violence among workers in the university was rare. These findings may be due to the fact that there exist regulatory sanctions for perpetrators of violence in any work place including the University of Port Harcourt [27] [35]. These may include various forms of punishments ranging from suspension with or without pay, demotion to dismissal/termination of work. The fear of these forms of punishment may propel workers to control their anger and not allow it to degenerate to violence. This finding is in agreement with earlier study in which all regions which participated in the study saw violence and harassment at work as important headed by the Eastern-Mediterranean participants (80\%), but Africans perceive this as the least important issue to be addressed (32\%) [19]. The stress that results from occupational violence has been estimated to contribute between $10 \%$ to $30 \%$ of workers' compensation claims [33].

From the study, majority of the psychosocial hazards were perpetrated by bosses particularly workplace verbal aggression. It follows naturally that since bosses are at higher ranks and status compared to their subordinates, the latter 
are much more likely to be victims of these forms of psychosocial hazards. Occasionally, the bosses use them with the intention of being corrective measures, but they have often been found to be counter-productive [19]. Threats and actual attack occurred with the least prevalence and threats were mostly perpetrated by bosses. Physical aggression was almost equally perpetrated by both bosses as well as subordinates. However the study found an interesting trend in the level of perpetration by subordinates in racial discrimination, where the prevalence was almost the same with the bosses.

A number of risk factors were assessed ranging from changes in the working population, job content, work load, career development, home-work interface, lack of social support to lack of interactions. From the study, work load was identified as the most prevalent risk factor, followed by home-work interface, interpersonal relationship and job content while working alone at night was the least. This finding is in line with earlier documentation that the most studied core contributing factors to psychosocial risks and work-related sload and work context [22] [23] [29] [36]. However, new and precarious forms of contracts in the context of the unstable labour market (employment conditions), increased vulnerability of workers in the context of globalization, new forms of employment contracts, and the feeling of job insecurity have been identified as important emerging psychosocial risks [45] [46] [50]. It has equally being found that where more of the contributing factors are present, increased levels of stress are likely to result due to synergism [50].

The content, context and volume of work which a worker has to do and accomplish within specified time has been found to be important determinant of psychosocial hazard. This description is in line with a documented definition of work-related stress as a pattern of reactions that occurs when workers are presented with work demands not matched to their knowledge, skills or abilities and which challenge their ability to cope [2]; and when there is a perceived imbalance between demands and environmental or personal resources, reactions may include physiological responses (for example increased heart rate, blood pressure, hyperventilation, as well as secretion of "stress" hormones such as adrenaline and cortisol), emotional responses (for example feeling nervous or irritated), cognitive responses (for example, reduction or narrowing of attention and perception, forgetfulness), and behavioural reactions (for example aggressive, impulsive behaviour, making mistakes). These will certainly make the worker vulnerable to poor performance which may ensue certain forms of psychosocial hazards from their bosses or employers.

Another important set of risk factors are the narrow space and opportunity to develop in the service as seen in lack of career development, lack of opportunity to grow on the job and advance. This may sometime translate into lack of or delayed promotion and poor knowledge about the job. Worse still, at other time, a worker's promotion may be deliberately delayed or even stopped without any cogent reason or explanation.

From the study, lack of opportunity for career development and job advance- 
ment were identified as important risk factors for psychosocial hazards by respondents. This is expected because a worker that is affected by any of the factors mentioned here will be wallowing in pain and will certainly loose all zeal to put in all his or her best due to lack of motivation [37]. As this happens, there will gradually be reduced productivity by the worker. This may lead to various forms of occupational violence. This agrees with the proposition of Cox and Griffith that workers also have work-related stress when despite rendering perceived important work, there is all indication instead that their efforts are not adequately rewarded [6], and this greatly dampen workers motivation [37]. Appreciation and rewards even verbal are important motivating factors which fuel or increase performance.

The next risk factor that was found in this study was home-work interface. This risk factor mostly affects women and interestingly, psychosocial hazards were more prevalent among women than the men in this study. A number of studies have supported this finding [41] [51] [52] [53]. Women manage the home fronts and it has been said that they do thrice as much work as men. For these reasons, they may experience burnout more easily than men [21] [39] [41]. A number of measures can be put in place to address issues of workplace psychosocial hazards in any organizations. Figure 1 shows identified possible solutions by participants in this study of which Periodic In service Training and Enlightenment of Workers were among the ones which the participants identified to be the most likely effective measures.

\section{Conclusion}

The findings from this study revealed that the occurrence of sexual harassment among the workers at the University of Port Harcourt is common. The results indicate that there is urgent need for the University to institute appropriate occupational health and safety measures to reduce the harmful occurrences of psychosocial hazards in the institution in other to improve the working environment, and consequently workers health and wellbeing as well as overall productivity.

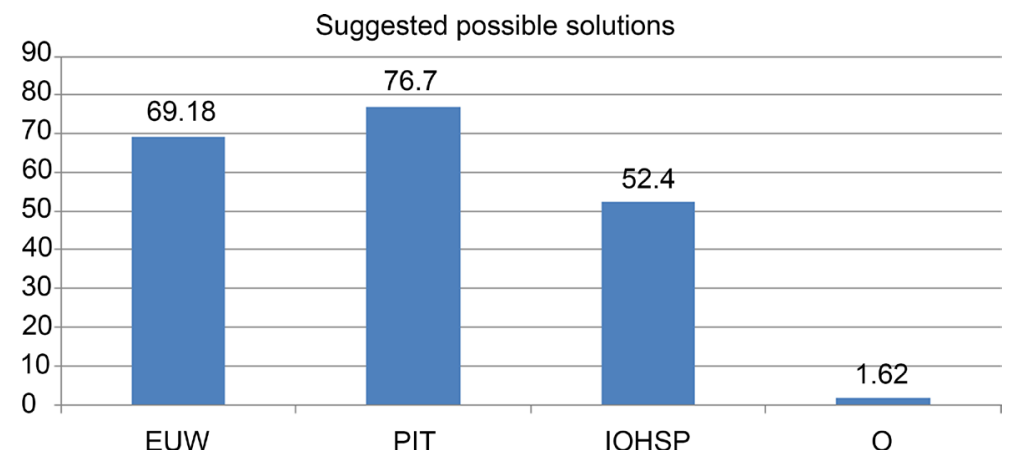

Figure 1. Showing suggested possible solutions that could reduce psychological hazards at workplaces in University of Port Harcourt. (Enlightenment of University workers (EUW), Periodic in-service training (PIT), Introduction of occupational health and safety programmes in the university (IOHSP), Others $(\mathrm{O})$ ). 


\section{Recommendations}

Base on the findings from this study, we recommend periodic in-service training (PIT), regular enlightenment, special orientation programmes, periodic awareness-raising campaigns and educational activities on prevailing occupational risk factors. Also, there is need for the introduction of occupational health and safety programmes at workplaces and in the educational curriculum of tertiary institutions as well as establishment of an Occupational risk and hazard management/ Occupational rehabilitation centre.

\section{References}

[1] Chappell, D. and Di Martino, V. (2000) Violence at Work. International Labour Office, Geneva.

[2] Comcare (2006) What Is "Stress" and What Is "Psychological Injury"? http://www.comcare.gov.au/stress_and_psychological_injury_information_portal/w $\underline{\text { hat_is }}$

[3] Caulfield, N., Chang, D., Dollard, M.F. and Elshaug, C. (2004) A Review of Occupational Stress Interventions in Australia. International Journal of Stress Management, 11, 149-166. https://doi.org/10.1037/1072-5245.11.2.149

[4] Baker, C.N. (2005) Blue-Collar Feminism: The Link between Male Domination and Sexual Harassment. In: Gruber, J.E. and Morgan, P., Eds., The Company of Men: Male Dominance and Sexual Harassment, Northeastern University Press, Boston, 242-270.

[5] Beale, D., Clarke, D., Cox, T., Leather, P. and Lawrence, C. (1999) System Memory in Violent Incidents: Evidence from Patterns of Reoccurrence. Journal of Occupational Health Psychology, 4, 233-244. https://doi.org/10.1037/1076-8998.4.3.233

[6] Cox, T. and Griffiths, A. (2010) Work-Related Stress: A Theoretical Perspective. In: Leka, S. and Houdmont, J., Eds., Occupational Health Psychology, Wiley-Blackwell, Chichester, 31-56.

[7] De Bruin, G.P. and Taylor, N. (2005) Development of the Sources of Work Stress Inventory. South African Journal of Psychology, 35, 748-765. https://doi.org/10.1177/008124630503500408

[8] Dollard, M.F. (2006) Throwaway Workers. In Psych, 28, 8-12.

[9] Krieger, N. (2004) Embodying Inequality: Epidemiologic Perspectives. Baywood, Amityville.

[10] Rosskam, E. (2002) Working at the Check-In: Consequences for Worker Health and Management Practices. Université de Lausanne-Ecole des Hautes Etudes Commerciales, Lausanne.

[11] Parent-Thirion, A., Macías, E., Hurley, J. and Vermeylen, G.G. (2007) Fourth European Working Conditions Survey. European Foundation for the Improvement of Living and Working Conditions. Office for Official Publications of the European Communities, Luxembourg.

[12] Wooding, J. and Levenstein, C. (1999) The Point of Production: Work Environment in Advanced Industrial Societies. Guilford Press, New York.

[13] Yen, I.H., et al. (1999) Racial Discrimination and Alcohol-Related Behavior in Urban Transit Operators: Findings from the San Francisco Muni Health and Safety Study. Public Health Reports, 114, 448-458. https://doi.org/10.1093/phr/114.5.448

[14] Quinn, M.M. (2003) Occupational Health, Public Health, Worker Health. American 
Journal of Public Health, 93, 526. https://doi.org/10.2105/AJPH.93.4.526

[15] Siegrist, J. and Marmot, M. (2004) Health Inequalities and the Psychosocial Environment-Two Scientific Challenges. Social Science and Medicine, 58, 1463-1473. https://doi.org/10.1016/S0277-9536(03)00349-6

[16] Schrijvers, C.T.M., van de Mheen, H.D., Stronks K. and Mackenbach, J.P. (1998) Socioeconomic Inequalities in Health in the Working Population: The Contribution of Working Conditions. International Journal of Epidemiology, 27, 1011-1018. https://doi.org/10.1093/ije/27.6.1011

[17] Rospenda, K. (2002) Workplace Harassment, Services Utilization and Drinking Outcomes. Journal of Occupational Health Psychology, 7, 141-155. https://doi.org/10.1037/1076-8998.7.2.141

[18] Richman, J., Rospenda, K., Nawyn, S., Flatherty, J., Fendrich, M., Drum, M. and Johnson, T. (1999) Sexual Harassment and Generalised Workplace Abuse among University Employees: Prevalence and Mental Health Correlates. American Journal of Public Health, 89, 358-363. https://doi.org/10.2105/AJPH.89.3.358

[19] Kortum, E. (2007) Work-Related Stress and Psychosocial Risks: Trends in Developing and Newly Industrialized Countries. The Global Occupational Health Network Newsletter, Special Issue, 3-6.

[20] Dollard, M.F. and Knott, V. (2004) Incorporating Psychosocial Issues into Our Conceptual Models of OHS. Journal of Occupational Health and Safety Australia and New Zealand, 20, 345-358.

[21] Duxbury, L. and Higgins, C. (2001) Work-Life Balance in the New Millenium: Where Are We? Where Do We Need to Go? CPRM Discussion Paper No. W|12, Canadian Policy Research Network, Ottawa.

[22] Concha-Barrientos, M., Imel Nelson, D., Driscoll, T., Steenland, N.K., Punnett, L., Fingerhut, M.A., Prüss-Üstün, A., Leigh, J., Tak, S. and Corvalan, C. (2004) Selected Occupational Risk Factors. In: Ezzati, M., Lopez, A.D., Rodgers, A. and Murray, C.J.L., Eds., Comparative Quantification of Health Risks. Global and Regional Burden of Diseases Attributable to Selected Major Risk Factors, WHO, Geneva, 1651801.

[23] Johnstone, R., Quinlan, M. and McNamara, M. (2011) OHS Inspectors and Psychosocial Risk Factors: Evidence from Australia. Safety Science, 49, 547-557. https://doi.org/10.1016/j.ssci.2010.09.016

[24] Kennedy, S. (2004) Organisational Change Affects Work Stress and Work-Family Balance. Australian and New Zealand Journal of Family Therapy, 22, 105-106. https://doi.org/10.1002/j.1467-8438.2001.tb01317.x

[25] Leka S. and Cox, T. (2008) The Future of Psychosocial Risk Management and the Promotion of Well-Being at Work in the European Region: A PRIMA Time for Action. In: Leka, S. and Cox, T., Eds., The European Framework for Psychosocial Risk Management, I-WHO, Nottingham, 174-184.

[26] Wegman, D.H. (2006) Aging and Globalization. Medicina del lavoro, 97, 137-142.

[27] Ekore, J.O. (2007) Policy on Psychosocial Hazards Contributing to Work-Related Stress: Awareness and Implementation in Nigeria. WHO GOHNET Special Newsletter.

[28] Kinman, G. and Jones, F. (2005) Lay Representations of Workplace Stress: What Do People Really Mean When They Say They Are Stressed? Work \& Stress, 19, 101 120. https://doi.org/10.1080/02678370500144831

[29] Rydstedt, L.W., Johansson, G. and Evans, G.W. (1998) A Longitudinal Study of Workload, Health and Well-Being among Male and Female Urban Bus Drivers. 
Journal of Occupational \& Organizational Psychology, 71, 35-45. https://doi.org/10.1111/j.2044-8325.1998.tb00661.x

[30] Takala, J. (2002) Life and Health Are Fundamental Rights for Workers (Interview). Labour Education, 1, 1-7.

[31] Ettner, S.L. and Grzywacz, J.G. (2001) Workers' Perceptions of How Jobs Affect Health: A Social Ecological Perspective. Journal of Occupational Health Psychology, 6, 101-113. https://doi.org/10.1037/1076-8998.6.2.101

[32] Senol-Durak, E., Durak, M. and Gencoz, T. (2006) Development of Work Stress Scale for Correctional Officers. Journal of Occupational Rehabilitation, 16, 157-168. https://doi.org/10.1007/s10926-005-9006-Z

[33] Hoel, H., Sparks, K. and Cooper, C. (2001) The Cost of Violence/Stress at Work and the Benefits of a Violence/Stress-Free Working Environment. Report Commissioned by the International Labour Organization, University of Manchester, Manchester.

[34] Flannery, R. (1996) Violence in the Workplace, 1970-1995: A Review of the Literature. Aggression \& Violent Behaviour, 1, 57-68. https://doi.org/10.1016/1359-1789(95)00005-4

[35] Ephraim, A. (2009) Putting Occupational Health on the Political Agenda in Nigeria. The Nigerian Village Square, 13 March. http://www/nigeriavillagesquare.com

[36] Rosengren, A., Hawken, S., Ônpuu, S., Sliwa, K., Zubaid, M., Almahmeed, W.A., Blackett, K.N., Sitthiamorn, C., Sato, H. and Yusuf, S. (2004) Association of Psychosocial Risk Factors with Risk of Acute Myocardial Infarction in 11119 Cases and 13648 Controls from 52 Countries (the INTERHEART Study): Case-Control Study. The Lancet, 364, 953-962. https://doi.org/10.1016/S0140-6736(04)17019-0

[37] Stillwell, B. (2001) Health Worker Motivation in Zimbabwe. Internal Report for the Department of Organization and Healthcare Delivery. World Health Organization, Geneva.

[38] Premji, S. (2011) Building Healthy and Equitable Workplaces for Women and Men: A Resource for Employers and Workers Representatives. Protecting Workers' Health Series No. 11, World Health Organization, Geneva.

[39] Heymann, J. (2006) Forgotten Families: Ending the Growing Crisis Confronting Children and Working Parents in the Global Economy. Oxford University Press, New York. https://doi.org/10.1093/acprof:oso/9780195156591.001.0001

[40] Nilvarangkul, K., Wongprom, J., Tumnong, C., Supornpun, A., Surit, P. and Srithongchai, N. (2006) Strengthening the Self-Care of Women Working in the Informal Sector: Local Fabric Weaving in Khon Kaen, Thailand (Phase I). Indian Health, 44, 101-107. https://doi.org/10.2486/indhealth.44.101

[41] Chandola, T. and Jenkinson, C. (2000) The New UK Statistics Socio-Economic Classification (NS-SEC); Investigating Social Class Differences in Self-Reported Health Status. Journal of Public Health Medicine, 22, 182-190. https://doi.org/10.1093/pubmed/22.2.182

[42] Rose, D. and O’Reilly, K. (1997) Constructing Classes: Towards a New Social Classification for the UK. Office of National Statistics, London.

[43] Wright, E.O. (1997) Classes Count: Comparative Studies in Class Analysis. Cambridge University Press, Cambridge.

[44] Sadock, V.J. and Sadock, V.A. (2007) Kaplan and Sadock's Synopsis of Psychiatry: Behavioral Sciences/Clinical Psychiatry. Lippincott Williams \& Wilkins, Philadelphia.

[45] Quinlan, M., Mayhew, C. and Bohle, P. (2001) The Global Expansion of Precarious 
Employment, Work Disorganization and Consequences for Occupational Health: A Review of Recent Research. International Journal of Health Services, 31, 335-414. https://doi.org/10.2190/607H-TTV0-QCN6-YLT4

[46] International Labour Office (2010) List of Occupational Diseases. ILO Publication, Geneva.

http://www.ilo.org/wcmsp5/groups/public/---ed_protect/---protrav/---safework/do cuments/meetingdocument/wcms_125137.pdf

[47] Standing, H. and Nicolini, D. (1997) Review of Work-Related Violence. Health \& Safety Executive Contract Research Report 143/1997, HSE Books, Sudbury.

[48] Leather, P., Lawrence, C., Beale, D., Cox, T. and Dickson, R. (1998) Exposure to Occupational Violence and the Buffering Effects of Intra-Organizational Support. Work \& Stress, 12, 161-178. https://doi.org/10.1080/02678379808256857

[49] Vecchio, R.P. (1995) It's Not Easy Being Green: Jealousy and Envy in the Workplace. Research in Personnel \& Human Resources Management, 13, 201-244.

[50] Messing, K. (1998) One Eyed Science: Occupational Health and Women Workers. Temple University Press, Philadelphia.

[51] EU-OSHA (2009) OSH in Figures: Stress at Work-Facts and Figures. Office for Official Publications of the European Communities, Luxembourg.

[52] Smyre, P. (1992) Women and Health. Women and World Development Series. http://www.ilo.org/public/libdoc/ilo/P/09708(2000-118-119)37-49.pdf

[53] Zahm, S.H. (2000) Women at Work. In: Goldman, M.B. and Hatch, M.C., Eds., Women and Health, Academic Press, San Diego. https://doi.org/10.1016/B978-012288145-9/50040-1

[54] Ristic, D., Stankovic, M. and Savic, S. (2008) Risk Assessment Matrices, Dependability and Quality Management. Research Center of Dependability and Quality Management, Prijevor.

Submit or recommend next manuscript to OALib Journal and we will provide best service for you:

- Publication frequency: Monthly

- 9 subject areas of science, technology and medicine

- Fair and rigorous peer-review system

- Fast publication process

- Article promotion in various social networking sites (LinkedIn, Facebook, Twitter, etc.)

- Maximum dissemination of your research work

Submit Your Paper Online: Click Here to Submit

Or Contact service@oalib.com 